\title{
Energy Management of PEMFC and NiMH Battery on 3-wheels Hybrid Electric Vehicle Equipped with CVT
}

\section{DEDY RAMDHANI HARAHAP ${ }^{*}$, WEI-CHIN CHANG ${ }^{2}$, SUGENG ARIYONO ${ }^{3}$}

\author{
${ }^{1}$ Politeknik Manufaktur Negeri Bangka Belitung, Bangka Belitung, Indonesia \\ ${ }^{2}$ Southern Taiwan Univiersity of Science and Technology (STUST), Tainan, Taiwan \\ 3 Politeknik Negeri Semarang (Polines), Semarang, Indonesia \\ *Email: dedy@polman-babel.ac.id
}

Received 20 Mei 2021 | Revised 21 Juni 2021 | Accepted 28 Juni 2021

\begin{abstract}
ABSTRAK
Penelitian ini mengelola energi dari PEMFC yang diatur untuk mengamati konsumsi energi, kecepatan maksimum, dan kemampuan kendaraan dalam melakukan pendakian. Pemodelan kendaraan listrik dikerjakan menggunakan ADVISOR. Fuel cell yang digunakan 200W sebagai sumber energi utama yang dikombinasikan dengan baterai NiMH sebagai sumber energi cadangannya. Masing-masing baterai NiMH memiliki tegangan sebesar 1,2 V dan 1,9 AH. Kinerja PEMFC dan baterai NiMH diamati dengan memberikan beban sesuai kebutuhan daya pada kendaraan hibrida. Hasil pengujian menunjukkan daya maksimum PEMFC antara 40-60\% daya baterai NiMH sehingga kendaraan dapat tetap bergerak. Energi dipasok oleh baterai ketika daya kendaraan lebih rendah dari 40\% sehingga PEMFC dapat berhenti memasok energinya. Ketika daya yang dibutuhkan lebih besar dari daya maksimum PEMFC maka baterai NiMH akan menyeimbangkan pasokan daya ke kendaraan. Mobil hibrida dapat menanjak pada kemiringan 3,5\%, konsumsi bahan bakar 40,6 liter/100 km, jarak tempuh sejauh 33,9 m/ 5 det, dan 0,4 km/26,1 det.
\end{abstract}

Kata kunci: Manajemen Energi , ADVISOR, PEMFC, NiMH, CVT

\begin{abstract}
In this research, the PEMFC energy management were set to inspect energy usage, maximum speed, and the ability of the vehicle to climb. The modeling of the electric vehicle is carried out using ADVISOR. The fuel cell with 200W as the main energy source in combination with NiMH batteries as energy source support. Every $\mathrm{NiMH}$ battery has a $1.2 \mathrm{~V}$ and $1.9 \mathrm{AH}$. The performance of PEMFC and NiMH batteries was observed by providing a load according to the power requirements of the hybrid car. The test results indicate the maximum power of the PEMFC around $40-60 \%$ of the NiMH battery power so the vehicle can keep moving. The battery will supply the energy when the vehicle power is lower than $40 \%$ so the PEMFC can stop supplying its energy. When the power needed is larger than the PEMFC maximum power then the NiMH battery will balance the power supply to the car. The hybrid car able to climb a 3.5\% slopping road, fuel consumption 40.6 liters/ $100 \mathrm{~km}$, the distance as far as $33.9 \mathrm{~m} / 5 \mathrm{~s}$ and $0.4 \mathrm{~km} / 26.1 \mathrm{~s}$.
\end{abstract}

Keywords: Energy Management, ADVISOR, PEMFC, NiMH, CVT 


\section{INTRODUCTION}

The development technologies using renewable alternative energy such as fuel cells, wind power, solar energy, and batteries are now growing. This energy sometimes uses in some small portable devices such as smartphones, laptops, UAVs, TV portable, which considerable amount of energy (Alaswad, 2016)(Hwang, 2012)(Sulaiman, 2015). In the transportation sector, PEMFC are fascinating for the automotive industries because of their ability to use hydrogen makes the energy conversion efficiencies is higher than the internal combustion engines (ICE). PEMFC produce only power and water so it will not produce harmful gas to the organism and the surroundings areas. There are many different kinds of hybrid power-train structures available now. The propulsion system of a hybrid vehicle can be a loadfollowing structure or a load leveled source structure, an energy hybrid structure, or a power hybrid structure (Das, 2017)(Rodrigue, 2017)(Wu, 2016). The battery bank system that starts to producing energy was selected then to generate energy used the hydrogen by the fuel cell will be analyzed. A fuel cell-battery hybrid small car utilized a 200 W PEMFC stack and 40-AA batteries of nickel-metal hydride stack in series, each battery produces $1.95 \mathrm{Wh}$ of energy, which was studied. The vehicle's model, fuel cell, battery, and motor were built, the transmission in this vehicle using CVT, and the strategies to control the energy for the vehicle were established using ADVISOR 2003 software. It is a useful simulation tools to design the vehicle, optimized the vehicle fulfillment, and help to optimize new and more advanced design models consist of the numerous power sources and drive schemes.

A fuel cell is like a battery because it can generate electricity from a reaction of electrochemical that also transform chemical potential energy into electrical power. as a by-product of this process also produces heat energy. However, the battery must discard when depleted or recharged by using an external electricity supply to generates the electrochemical reaction in the reverse direction so the battery can be used again as a power source (Garraín, 2011).
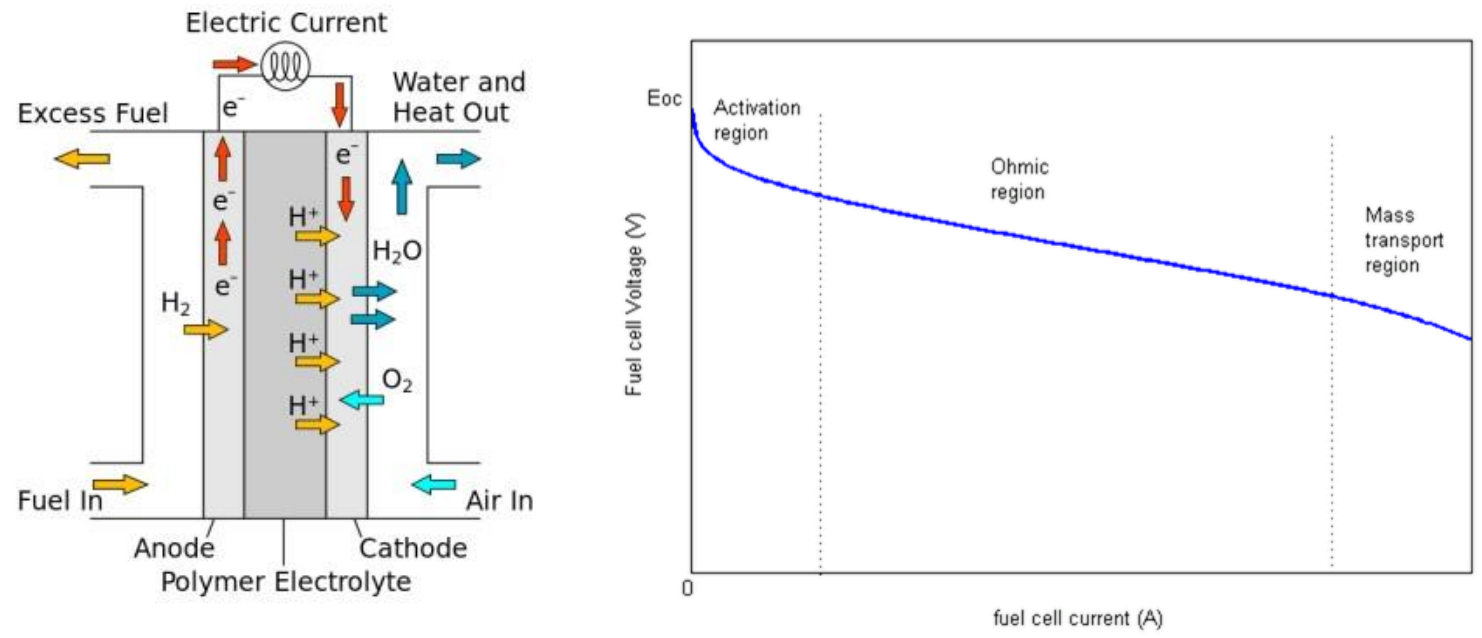

Figure 1. The PEMFC diagram and the Voltage-Current curve

Figure 1 shows the PEMFC process and the curve of Voltage-Current when operating the PEMF as energy source. The PEMFC efficiency is ideal to the number of energy drawn from it. Drawing more energy means drawing extra current, this intensify the losses in the PEMFC. In general, the greater power (current) drew, the lower the efficiency. The majority of losses display themselves as a voltage drop in the cell, so the cell efficiency is almost comparable to its voltage. The term 'Electric Vehicle' can be described as a vehicle with electrical or traction 
motor for its propulsion system. It should covers ground, air, and sea vehicles, but the fact is it has become accepted by both the scientific and industrialized group that 'Electric Vehicles' are ascribe exclusively to roadway cars except that specified. Under the term 'Electric Vehicle' (EV), subcategories exist Fuel Cell Electric Vehicle (FCEV), Hybrid Electric Vehicle (HEV), and Battery Electric Vehicle (BEV) vary in particular design conditions but part of the electrical technology in similar root. The energy source is limited, by engage multiple onboard energy systems that are specially design for the multifarious segments turn into a good solution (Rosario, 2007)(Sanlı, 2012).

\section{METHOD}

\subsection{Methodology}

This study will simulate the performance of the vehicle run by the fuel cell and NiMH battery using ADVISOR software. The simulation begins by establishing the vehicle model, driving cycle condition, power schemes, fuel converter, energy storage, motor, transmission, wheel/ axle, accessories, and powertrain then computing the parameters in the software. The relation between each component and the schematic diagram of the simulation data flow on how to configure those parameters using the Matlab/Simulink program will be explained in Figure 2 (Feroldi, 2009). The main parameter of this vehicle prototype is the vehicle glider mass, drag coefficient, drag force, rolling resistance coefficient, maximum speed/ velocity, and the drive train.

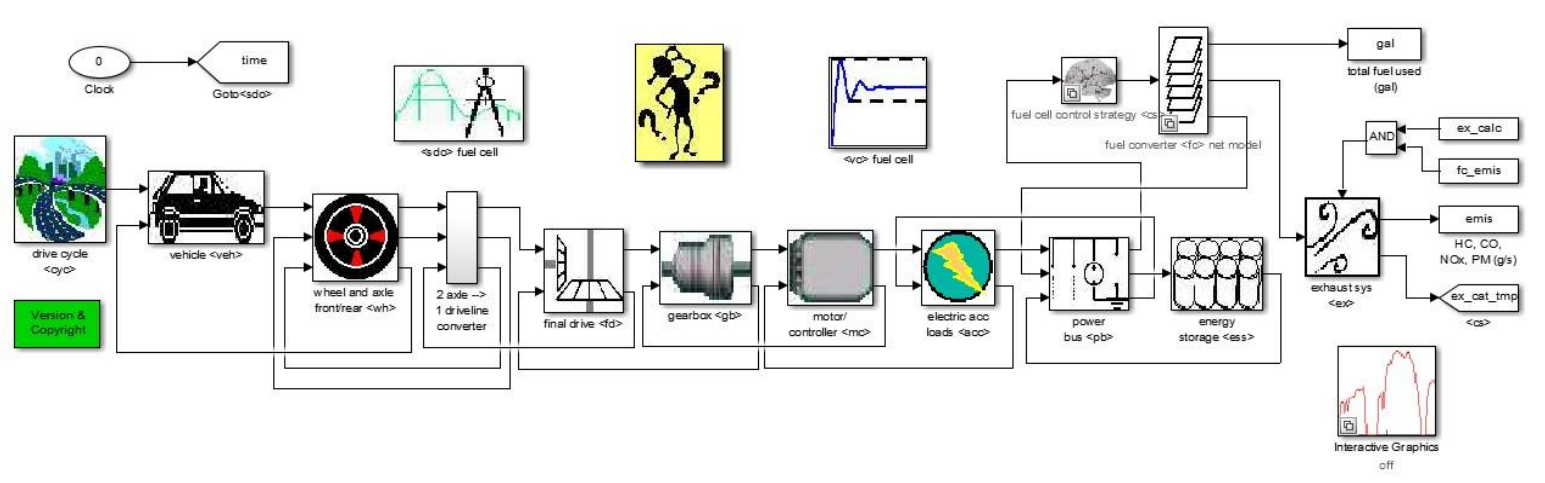

Figure 2. Fuel cell/ battery hybrid vehicle diagram

\subsection{Drivetrain Layout}

The vehicle drivetrain is the group of components that distribute power to the driving wheels, not including the engine or motor that generates the power that shown in Figure 3 . The engine operating speed and the wheels are different so the correct gear ratio must be matched. The transmission system for this vehicle is Continuously Variable Transmission (CVT) which can substitute the transmission ratio steplessly resulting in an immeasurable number of effective transmission ratios in-between maximum to minimum standard. This contrasts with other machine-driven transmissions that only acquiesce a few numbers of disparate variant gear ratios to be picked. The CVT flexibility grant the driving axle to maintain a uninterrupted angular velocity over the output velocities area. 

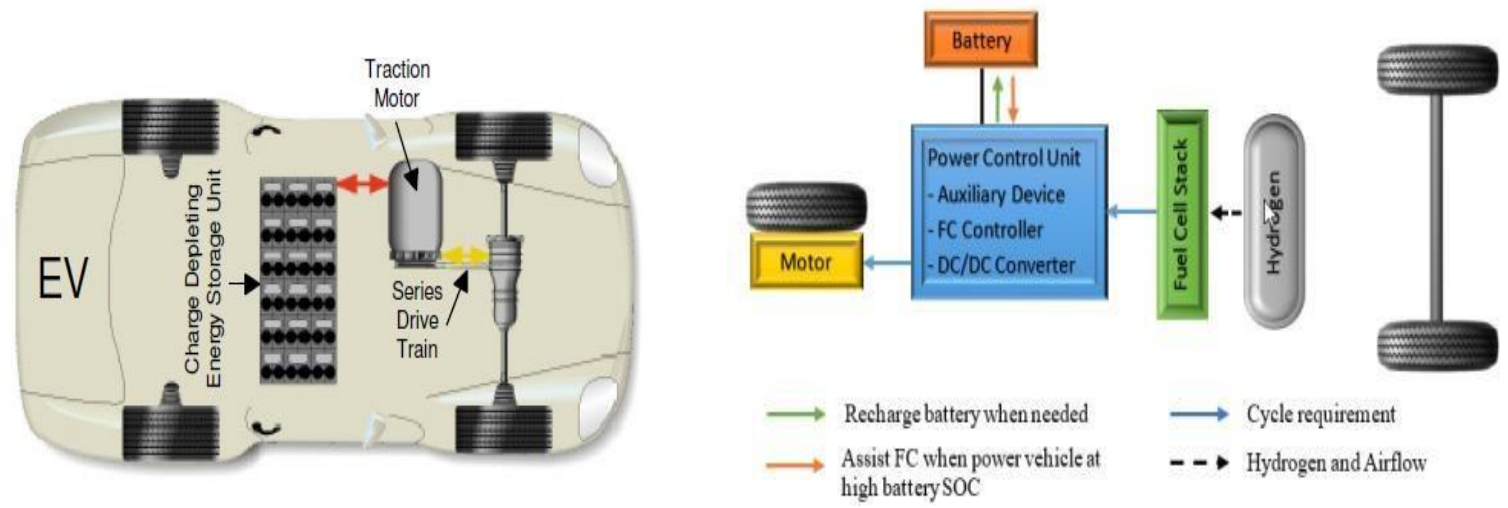

Figure 3. Fuel cell hybrid vehicle configuration
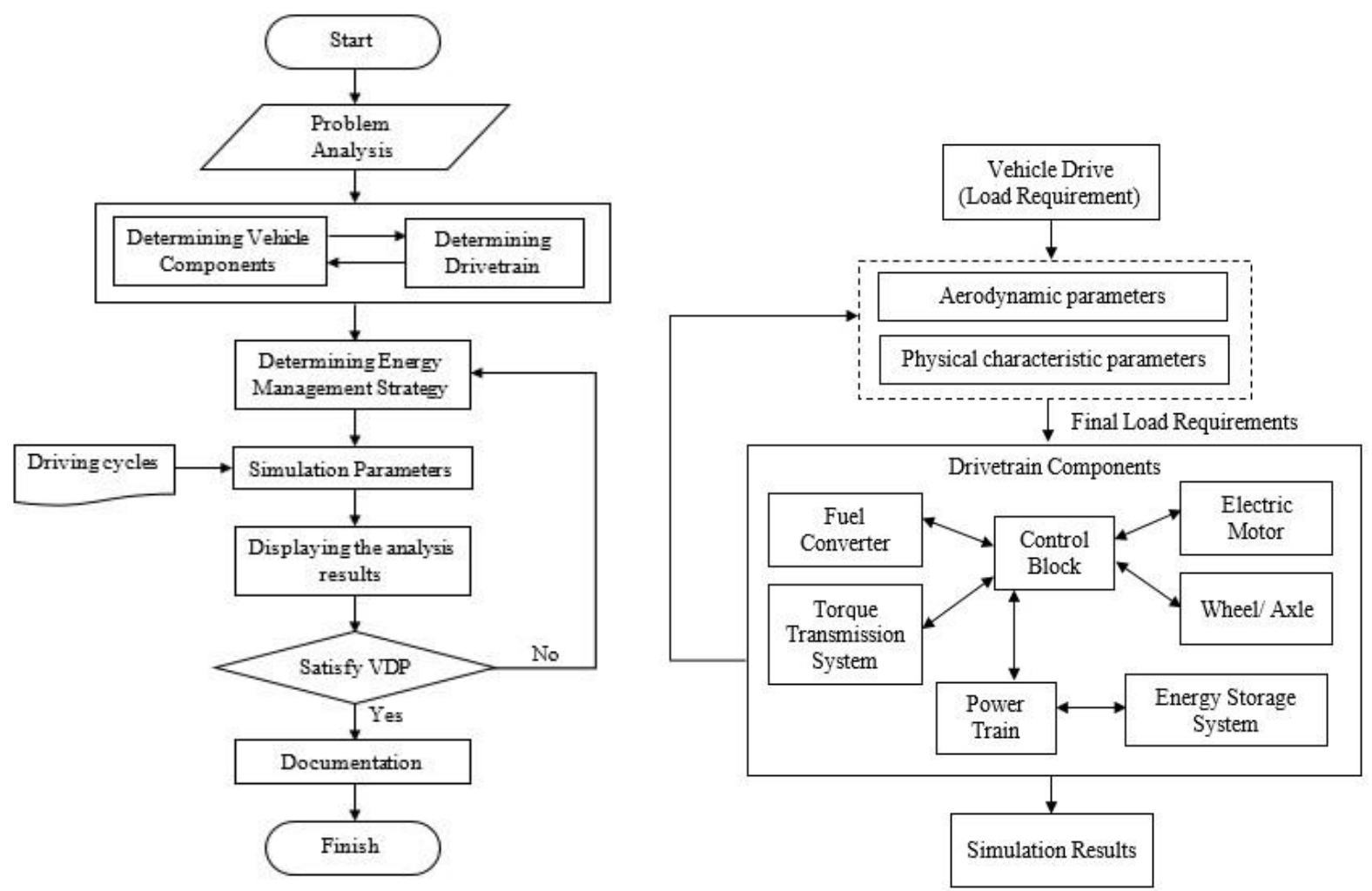

Figure 4. Research systematic method and the Schematic diagram of simulation data flow

Figure 4 show the schematic diagram managing the research according to actual condition and environment in the location. The diagram also describe the flow process to analyze the arrangement of the load requirement for the hybrid car from the fuel converter, torque transmission system, power train, wheel/ axle, Energy Storage System (ESS), etc.

\subsection{Simulation Parameter}

A Drive Cycle is a driving scenario that duplicates a individual driving styles while starting the car and making a short turnpike road trip, as an example while driving to the office. 


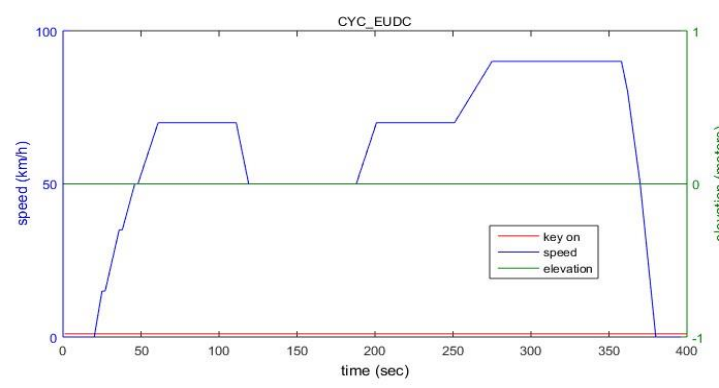

\begin{tabular}{lrl}
\hline Parameter & Index & unit \\
\hline Duration & $400 \mathrm{~s}$ \\
\hline Simulated distance & $6.61 \mathrm{~km}$ \\
\hline Maximum speed & $90 \mathrm{~km} / \mathrm{h}$ \\
\hline Average speed & $59.48 \mathrm{~km} / \mathrm{h}$ \\
\hline Maximum acceleration & $0.83 \mathrm{~m} / \mathrm{s}^{2}$ \\
\hline Maximum deceleration & $-1.39 \mathrm{~m} / \mathrm{s}^{2}$ \\
\hline Idle time & $41 \mathrm{~s}$ \\
\hline
\end{tabular}

Figure 5. Extra Urban Driving Cycle (EUDC) simulation test

The driving range is one of the key electric car measurements, the longer the driving range, the more car. Figure 5 show the Extra-Urban Driving Cycle (EUDC) driving conditions were selected for this project. The chart shows that the test procedures require a constantly changing speed. The Extra-Urban Driving Cycle (EUDC) contains a large portion of extreme acceleration at very high speeds up to $80 \mathrm{~km} / \mathrm{h}$, maximum speed is $120 \mathrm{~km} / \mathrm{h}$; low-powered cars are limited to $90 \mathrm{~km} / \mathrm{h}$ (Chew, 2014).

\section{RESULTS AND DISCUSSIONS}

\subsection{Vehicle Modelling}

The vehicle modeling, even if for conventional ICE vehicles, EVs, FCVs, HEVs acquired from the solid-body motion basic equation, as given in Equation (1) in its scalar configuration.

$$
F=m a
$$

This equation might be adjust with the specific forces, which are regularly implemented on vehicles and conceivably be rearranged into the form of Equation (2).

$$
F=m g C r r+12_{-} \rho C d A v 2+m a+m g \sin (\theta)
$$

\subsection{Drivetrain Component}

The vehicle drivetrain is the group of components that deliver power to the driving wheels that are composed of everything that makes the vehicle move includes the transmission to all the parts that allow the power from the engine to the wheels (Hassan, 2015). Each component configured and arranged as the vehicle drivetrain includes the vehicle portion after the transmission changes depending on whether a vehicle is front-wheel, rear-wheel drive, or any combination in between. The control strategy on managing energy is used to share the desired drive torque to make the power apparatus performance in their most efficient area (Hien, 2009)(Chew, 2014)(Markel, 2002).

\subsection{Fuel cell Modelling}

A 200W Horizon Fuel Cell is used to find out the characteristic of the fuel cell stack which the open-circuit voltage was $38 \mathrm{~V}$. The the stack produced $9.5 \mathrm{~A}$ maximum current, and the maximum power at $24 \mathrm{~V}$ was $200 \mathrm{~W}$. The arrangement was designed with an open-cathode configuration, and the stack contains 40 cells with an active area of $19 \mathrm{~cm}^{2}$ for each cell. There are two electric fans installed into the systems to accumulate the oxygen and draw out the arouse heat produced from the cell. The hydrogen fed to the system is $99.99 \%$ purity. The PEMFC stack hydrogen pressure was 0.45 bar, the flow rate is $2.6 \mathrm{~L} / \mathrm{min}$, the PEMFC power is 200 watts, and the fuel cell efficiency is $40 \%$. The measurement was fed into a personal 
computer (PC) and the performance was also measured using an electronic load to see the voltage to current polarization curve, as presented in Figure 6.

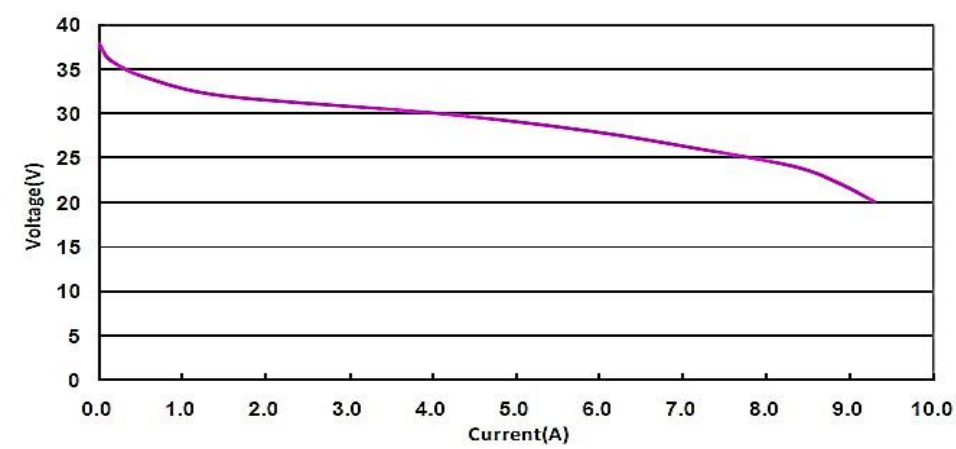

Figure 6. Fuel cell polarization curve at 0.45 bars

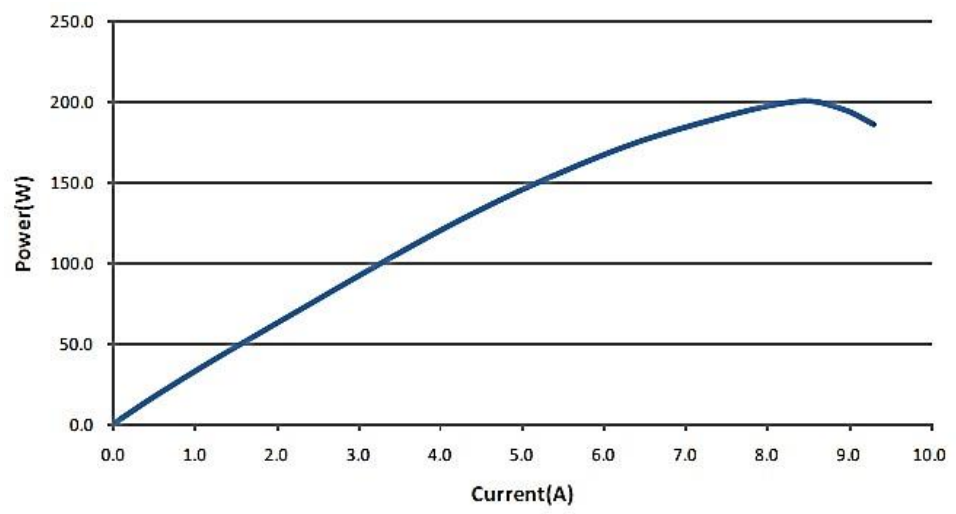

Figure 7. The power-Current curve of 200W PEMFC

Figure 7 is the fuel cell stack voltage-current polarization curve where the output voltage drop could be categorized into three regions. These phenomena can be represented by the Equation (3).

$$
V s t=N\left(E r-V a-V_{o h m}-V_{\text {conc }}\right)
$$

where $V_{s t}$ is the stack output voltage, $N$ is the cells number connecting in a stack; $E_{r}$ is theoretical cell potential, $V_{a}$ is the voltage loss due to reaction kinetic, $V_{o h m}$ is the resistance and $V_{\text {conc is }}$ the mass transport. These losses could be estimated using the specific equations. The reaction kinetic or activation voltage loss and the resistance or ohmic loss are designated by observational formula in Equation (4) and (5), respectively.

$$
\begin{aligned}
& V a=R T \alpha F_{-}-\ln \left({ }_{i} i_{o}\right)_{\mathrm{s}}, \\
& o h m=(R m+r) I
\end{aligned}
$$

Where $a$ and $i_{0}$ are the transfer coefficient and the exchange current density, respectively. The exchange current density, $i{ }_{i}$, influence by operating circumstance and the catalyst properties and should be set on experimentally. $R_{m}$ and $r$ are membranes and other component's resistances. The current density and the voltage were obtained experimentally. The affiliated parameters shown in the equation could be measured where the number of cells is 40 cells, the hydrogen pressure is 0.45 bar. 


\subsection{Transmission, Wheel/ Axle Modelling}

The wheel/ axle model transmits torque and speed request by the vehicle to the final drive, includes the effects of axle losses, tire slip, wheel, and axle inertia, and the friction brake defined with wheel diameter $0.356 \mathrm{~m}$ (14 in) and $3.6 \mathrm{~kg}$ of the wheel mass. In this modeling the transmission is set in fix ratio (1:1 ratio), so the speed of rotation of wheel similar to the rotation of motor electric. It assumed that the power required from the wheel is provided by the electric motor power. The PEMFC system operates some peripherals that genetically manage power as they keep up the gasses reaction within the fuel cell. ADVISOR defines the standard supplementary load data for employ with hybrid systems based on the mechanical supplementary load that was drawn from the machines and the electrical load that was drawn from the voltage or power bus (Andari, 2017). The supplementary load also configures the constant torque load on the engine and also the dc-to-dc converter efficiency applied in the systems. For the electrical accessory load set at 50W to support the auxiliary power in the vehicle systems to start up and shut down.

\subsection{Electric Motor Modelling}

This vehicle uses a MITSUBA motor model M0124D-V that usually applies for electric vehicle competition. This motor distributes far greater flexibility to car designers while substantially decreasing drivetrain losses which means less energy is wasted (during both acceleration and regenerative braking), causing the energy to propel the vehicle from the battery pack more available as shown in Figure 8.

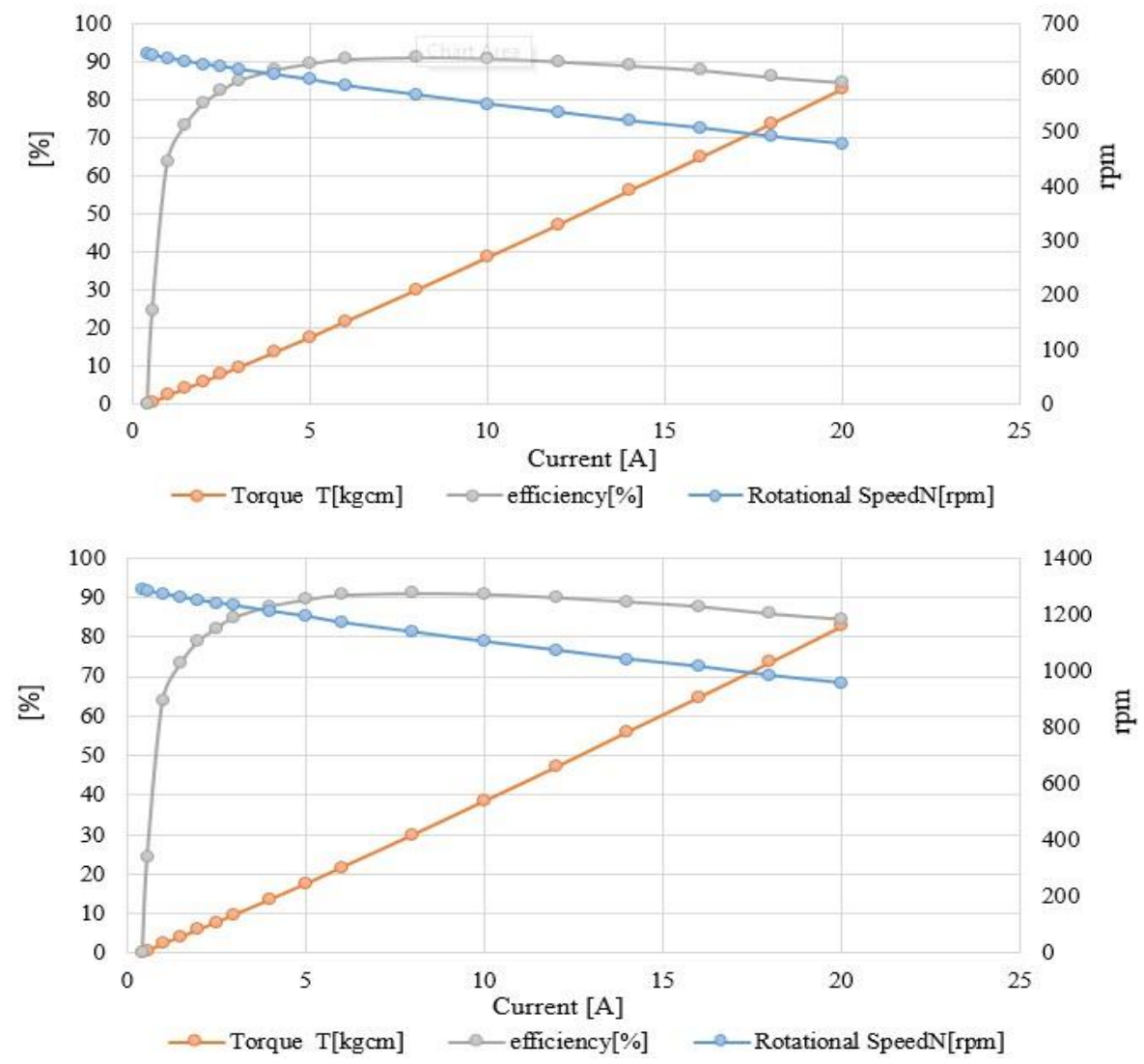

Figure 8. Mitsuba motor M0124D-V performance at 24V and 48V 


\subsection{Energy Management Strategy}

The control strategy is an algorithm that determines in every experimental time the power generation split within the PEMFC systems and the energy storage system (ESS) to accomplished the power balance amongst the energy sources and load power (Feroldi, 2009)(Rosario, 2007). The energy consumption used by the vehicle is performed by three modes; starting/ normal mode, accelerating mode, and steady mode. The accelerating mode will be split into two modes, the high-speed style, and the low-speed style. To disengage power from the NiMH battery and keep the PEMFC travel in its high-efficiency domain, so the PEMFCs maximum power operation parameters was set around $40 \%-60 \%$. The maximum rate of the increasing fuel cell converter was set at $180 \mathrm{~W} / \mathrm{s}$, and the maximum rate of decreasing was set at $-280 \mathrm{~W} / \mathrm{s}$. When the required car power is lower than $40 \%$ of the PEMFCs maximum power, the battery will deliver all the necessary power for the car, and the PEMFC will shut off. the NiMH battery will support power to stabilize PEMFC when the required power is larger than the PEMFCs maximum power. The fuel cell turns on when the battery SOC reaches its low limit at $40 \%$, and the highest desired battery was set at $80 \%$.

\subsection{Simulation Results}

The major outputs were plots from the ADVISOR simulations to showing the velocity profile and the State of Charge (SoC) as a function of time throughout a lap in the highway fueleconomy test. Figure 8 shows the results of hybrid configuration series following the EUDC driving cycle test for $400 \mathrm{~s}$ and able to travel along $6.61 \mathrm{~km}$ with $59.48 \mathrm{~km} / \mathrm{h}$ of speed. Figure 9 , shows the energy storage of the vehicle, and the amount of fuel consumed during the simulation in gram per kilowatt-hour is shown in Figure 12. Figure 11 shows the motor torque graph that shows the motor performance during the simulation when the vehicle tries to follow the EUDC driving cycle procedure. There are inclination and declination during the 400 seconds. The highest torque is when the vehicle attempts to reach the maximum speed of the requirement, $90 \mathrm{~km} / \mathrm{h}$. After few second, the vehicle already decelerates and maintain the speed at $59.48 \mathrm{~km} / \mathrm{h}$ in average. After $350 \mathrm{~s}$, the motor going to decelerate and finished the driving cycle test. The average motor controller efficiency is above $80 \%$ of the driving performance. It is obvious to show that the simulation results are ideal. Beside those simulation results that presented by ADVISOR, below are the figure that shows the acceleration and gradability test base on EUDC driving requirement.

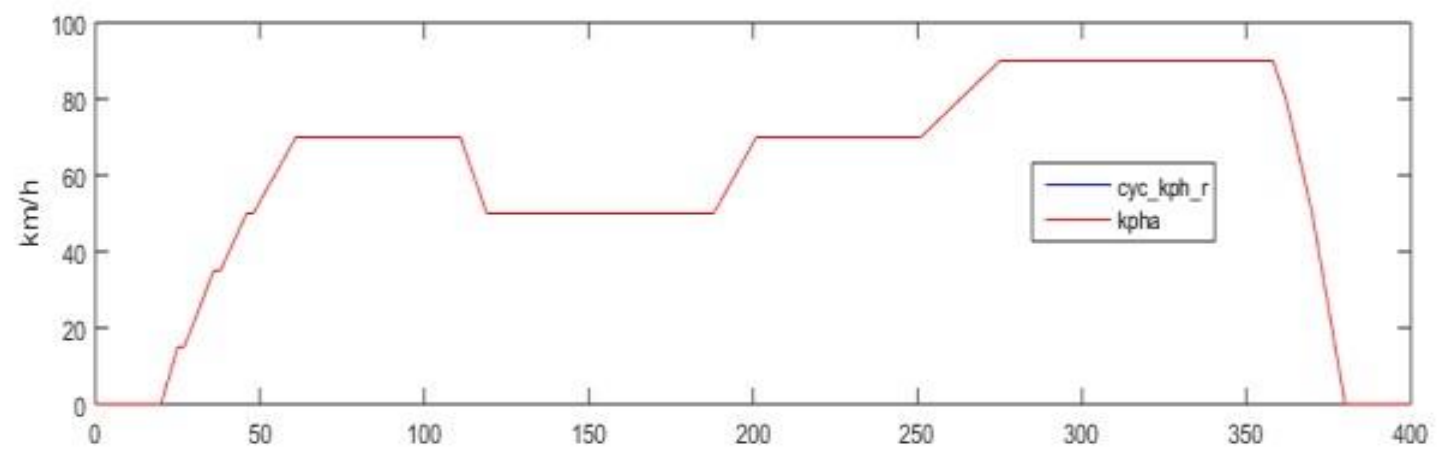

Figure 9. The vehicle driving test by EUDC 

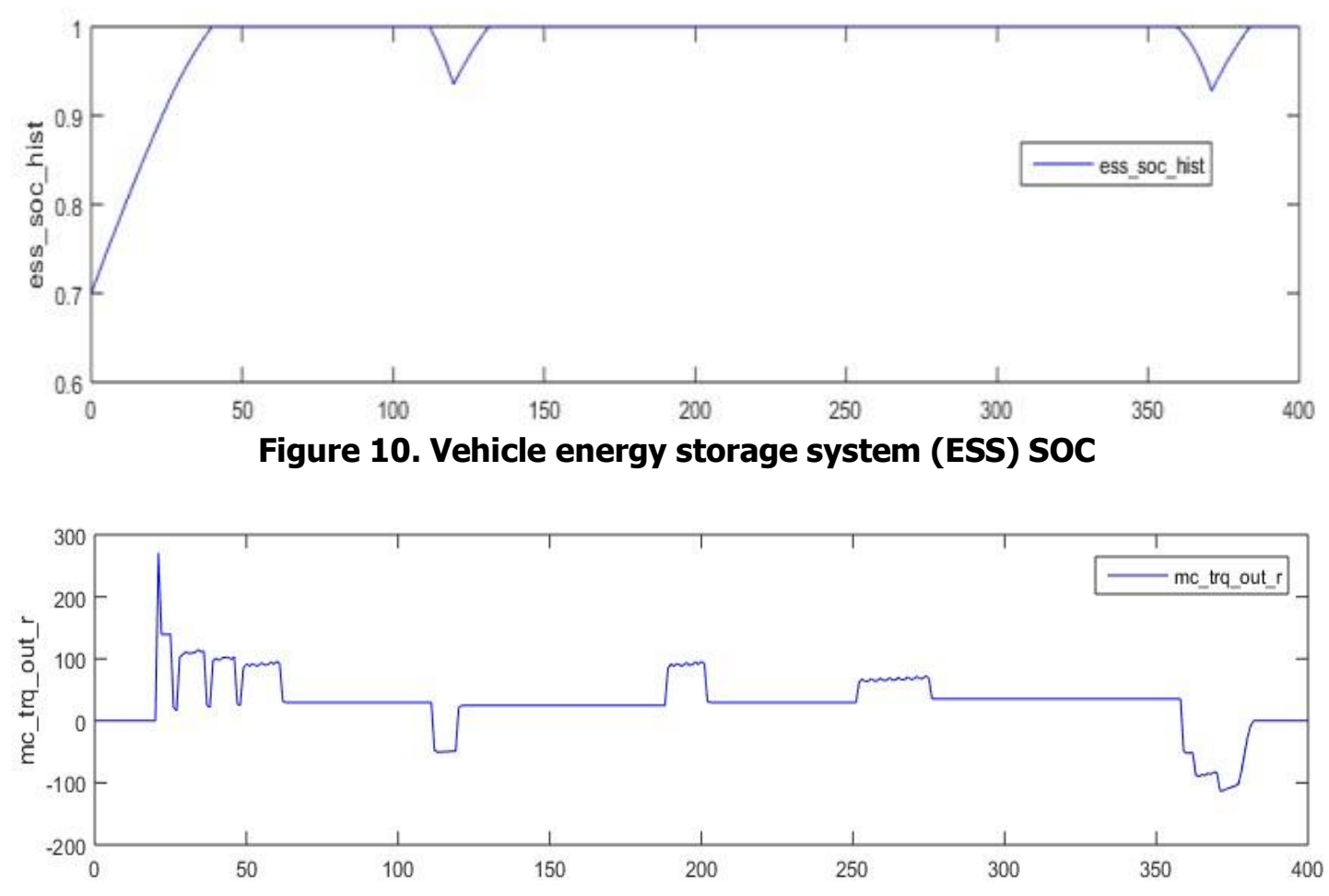

Figure 11. Vehicle motor torque

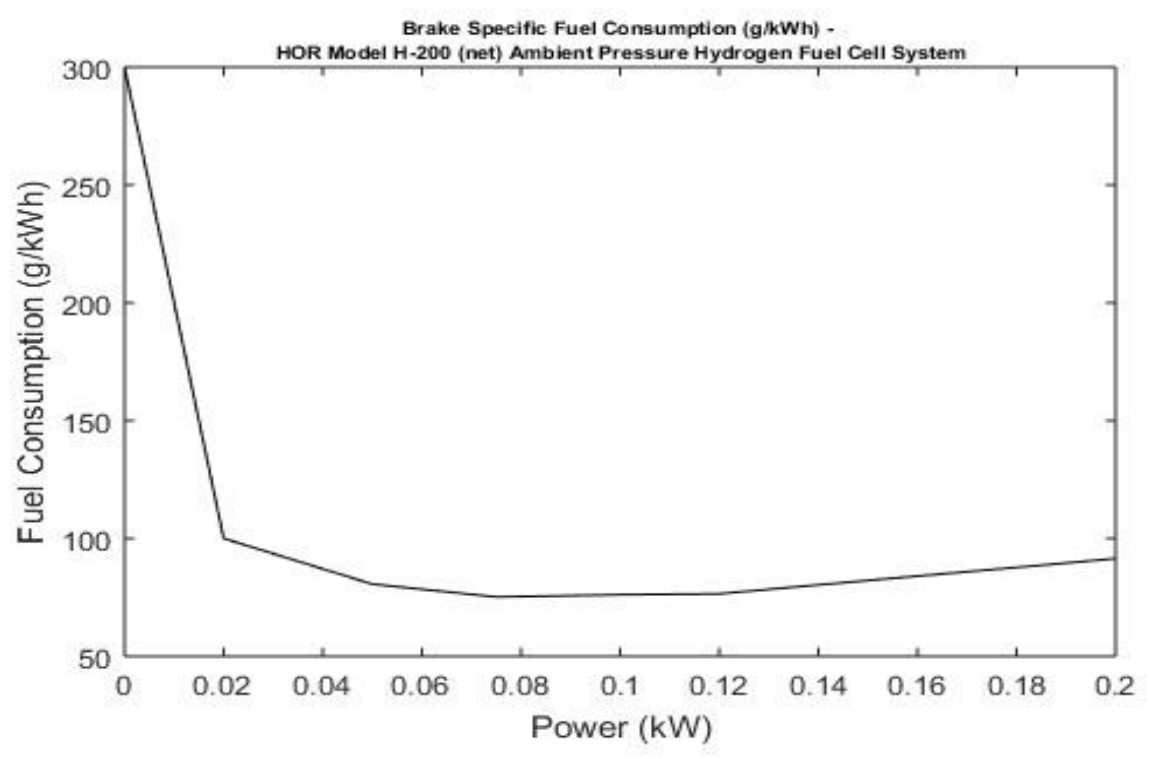

Figure 12. Vehicle fuel consumption

The maximum vehicle acceleration is $5.8 \mathrm{~m} / \mathrm{s}^{2}$, in five seconds the vehicle able to travel along 33.9 meters. Another result shows from this simulation of acceleration test is the ability of the vehicle to reach $0.4 \mathrm{~km}$ in 26.1 seconds, the fuel (hydrogen) usage about $40.6 \mathrm{~L} / 100 \mathrm{~km}$ equal to 2.7 liters of gasoline. The vehicle gradability is $3.5 \%$ which indicated that the vehicle's ability to climb the sloping road. 


\section{CONCLUSIONS}

The hybrid vehicle mode is starting mode, accelerating mode that separates into two parts, and steady mode. The Extra-Urban Driving Cycle (EUDC) was chosen for the simulation because it can use to simulate the electric vehicle driving performance to the achieved point, especially at a distance, maximum speed, and average speed, then another driving cycle that available in the software. The PEMFC maximum power operation range was set in between $40 \%-60 \%$ to retract power from the NiMH battery and to ensures the fuel cell operates in its high-efficiency domain. When the car power is lower than $40 \%$ of the PEMFCs maximum power then the battery will support the power for the car, on the other hand causing the PEMFS shut off. When the necessary power is larger than the PEMFCs maximum power then the battery will support power to stabilize it. The car can travel along 3.5\% sloping road gradability, the fuel usage about $40.6 \mathrm{~L} / 100 \mathrm{~km}$. In 5 seconds, the car can attain $33.9 \mathrm{~m}$ and need 26.1 seconds to travel along $0.4 \mathrm{~km}$.

\section{ACKNOWLEDGMENTS}

We would like to cherish our gratefulness to the Ministry of Education, Culture, Research, and Technology for the research grant. We also would like to honor Politeknik Negeri Semarang especially the Department of Mechanical Engineering that already allowed us to employ the laboratory to experiment. Moreover, the researcher from Polmanbabel who tries to use CVT in his research supported the Fuel Cell Laboratory of the Southern Taiwan University of Science and Technology (STUST) Taiwan.

\section{REFFERENCES}

Alaswad, A., Baroutaji, A., Achour, H., Carton, J., Al Makky, A., Olabi, A.G. (2016). Developments in fuel cell technologies in the transport sector. international journal of hydrogen energy, 41, 16499 - 16508.

Andari, W., Ghozzi, S., Allagui, H., Mami, A. (2017). Design, Modeling and Energy Management of a PEM Fuel Cell / Supercapacitor Hybrid Vehicle. International Journal of Advanced Computer Science and Applications, 8, 273 - 278.

Chew, K. W., Koay, C. K., \& Yong, Y. R. (2014). ADVISOR Simulation of Electric Vehicle Performance on Various Driving Cycles. International Journal of Innovative Science, Engineering, \& Technology, 1(8), 70 - 76.

Das, H. S., Tan, C. W., Yatim, A. H. M. (2017). Fuel cell hybrid electric vehicles: A review on power conditioning units and topologies. Renewable and Sustainable Energy Reviews, $76,268-291$.

Feroldi, D., Serra, M., Riera, J. (2009). Energy Management Strategies based on efficiency map for Fuel Cell Hybrid Vehicles. Journal of Power Sources, 190, 387 - 401. 
Garraín, D., Lechón, Y., Rúa, C. D. (2011). Polymer Electrolyte Membrane Fuel Cells (PEMFC) in Automotive Applications: Environmental Relevance of the Manufacturing Stage. Smart Grid and Renewable Energy, 2, 68 - 74.

Hassan, A., Mushtaq, Z., \& Rehman A.. (2015). Performance Analysis of Drive Train Configurations using ADVISOR. International Journal of Innovative Research in Advanced Engineering 2(1), 306 - 312.

Hien, P. M. (2009). A Simulation and Experiment Study of Small Fuel Cell/ Battery Hybrid Vehicle. (Master). Southern Taiwan University of Science and Technoogy,

Hwang, J., Chen, Y., Kuo, J. (2012). The study on the power management system in a fuel cell hybrid vehicle. international journal of hydrogen energy, 37, 4476 - 4489.

Markel, T., Brooker, A., Hendricks, T., Johnson, V., Kelly, K., Kramer, B., O’Keefe, M., Sprik, S., Wipke, K. (2002). ADVISOR: a systems analysis tool for advanced vehicle modeling. Journal of Power Sources 110, 255 - 266.

Rodrigue, J., Comtois, C., \& Slack, B. (2017). The Geography of Transport Systems (Vol. Fourth Edition). New York: Routledge.

Rosario, L. C. (2007). Power and Energy Management of Multiple Energy Storage Systems in Electric Vehicles. (Ph.D.). Cranfield University, United Kingdom.

Sanll, A. E., Gunlu, G., Aytac, A., Mat, M. (2012). Development of a power management unit for small portable direct borohydride fuel celleNiMH battery hybrid system. international journal of hydrogen energy, 37, 19103 - 19110.

Sulaiman, N., Hannan, M. A. , Mohamed, A., Majlan, E. H., Wan Daud, W. R. (2015). A review on energy management system for fuel cell hybrid electric vehicle: Issues and challenges. Renewable and Sustainable Energy Reviews, 52, 802 - 814.

Wu, J., Peng, J., He, H., \& Luo, J. (2016). Comparative analysis on the rule-based control strategy of two typical hybrid electric vehicle powertrain. Energy Procedia, 104, 384 389. 